\title{
Don Quixote in hebrew cyberspace
}

\section{Ziva Ben-Porat}

Tel Aviv University

zivabp@post.tau.ac.il

In the last decade are I have been working on the question of what is happening to the canon (or whatever has remained of it) as a major factor of cultural memory, after economic and social changes on the one hand and Feminism and Post-Colonialism on the other have effectively torn it to pieces leaving it as a historical relic? In particular, I have been trying to figure out the role of the canon in the digital era, when the internet is not just an incredibly powerful tool of dissemination but a new model of communication. I wandered about the relationship between a 14 year old blogger calling herself Ophelia and Shakespeare's Hamlet, or between a cyclist biking through the Alps in winter and Don Quixote; what does the appellation mean to the bloggers and what does it mean to their readers (at least, those that respond to the posts. In these two examples the common denominator is that both of them are bloggers addressing audiences comprised mostly of people who, as the evidence shows, have not read the texts or watched the play and have encountered them mostly in partial and often distorted audio, visual, dramatic or cinematic representations. Yet some of the major attributes of these Western Masterpieces are known to both writers and audiences in ways that show that at least these attributes partake of their communities cultural memory. 
Before sharing with you some of my findings I need to define my terms. For obvious reasons (the time constraints of an oral presentation) I combine this task with the outline of my argument. Throughout the paper and, in particular, its theoretical introductory part, I'll relate my work to Robert Alter's notions of canonicity and creativity (2000) and his insights on Cervantes' masterpiece (1975) as an embodiment of these notions.

1. Cultural memory, as I use the term, is not the aggregated reservoir of physical memorial sites and commemorating behaviors in themselves, the sum total of documents in archives, libraries, and museums (better named "cultural heritage"), or the set of myths and beliefs that stand in opposition to history (often termed "collective memory"), but that knowledge of the past and its major products which citizens of any culture share as a human group in a given moment.

2. Cultural memory results from repetitive exposure of a cultural group, in a given moment, to information and to artifacts (monuments, books, movies, pop songs, paintings and caricatures, etc.).

3. There are many channels for the dissemination of these artifacts (and the ideas and values associated with them): the educational systems (family included) and memory institutions, and in particular, mass media and other popular cultural strata. In the 3rd millennium the dominant channel is the web which seems to be not only a combined site of preservation and transformation, representation and misrepresentation, and dissemination as well as concealment, but a substitute for human memory as well. Socrates' prediction in Phaedrus, that the gift of writing will not be a remedy for the memory but, on the contrary, its true effects are likely to be the opposite - seems to be tested before our very 
eyes: people can rely on Google and Wikipedia for their knowledge of texts (and even of their inter-relations), but use these tools mostly under duress (namely, only when required to do it). Sheer referencing of canonic texts does not usually function as such a requirement; particularly when a participant in computer communication is familiar with a canon-related item via cultural memory even without having a real knowledge of the relevant text of origin.

4. Extensive exposure is related to canonization in two contradictory and complementary ways. On the one hand, those artifacts that achieve privileged positions are most likely to be represented in various forms and media. At the same time, as Alter has shown in his work on the Song of Songs, popularity might precede canonicity. In the "old" times, when canons were decided by arbiters of taste and mores, popularity-based canonization required allegorization. Similarly, allegorizing interpretations have been recruited in order to sustain and prolong a text's canonic position. This might explain Don Quixote's phenomenal transformation from a story relating the comic adventures of a madman to the symbolic representation of a steadfast idealist. In short, in accordance with the changed views of a text's meaning from significance to signification- I now believe that canonicity entails -rather than requires- thematic complexity. Needless to say, I used to believe the opposite. With respect to Don Quixote I do not claim that Unamuno's romantic idealistic interpretation or the self-consciousness of Cervantes' novel (as described in Partial Magic) are merely brilliant critical moves, not grounded in the text. I do believe, however, that they are more an outcome than a cause of the text's canonicity

5. As a creative source a cultural canon is therefore a particularly important tool for the construction, dissemination, and 
preservation of cultural memory. While acting as a means of exclusion a canon also functions as a counter-force against the inevitable reduction of cultural entities (e.g. the myth of Achilles) into linguistic units (idioms) or memes (disconnected memory units) of a special kind. 'Achilles' heel' used to communicate the notion of 'the weak point' is an example of the former; Romeo and Juliet as symbols of happy love provide an example of the latter (meme).

6. Alter's definition of the literary canon: "A [literary] canon is above all a trans-historical textual community" fits well into my notion of cultural memory, comprising both the notions of active (rather than archival) cultural memory and social institution.

7. As an attribute of a community, active cultural memory is expected to be a part of the individual memory of each community member.

8. As mass media in general and the blogosphere in particular reveal and cognitive psychology teaches us, individuals retain only certain attributes of canonized texts in active memory: names of authors, titles of works, names of major protagonists, a few scenes or episodes. The latter would usually be alluded to or represented in new media. At first they are perceived as attributes, actually synecdoche, but with time they function as independent entities. These decontextualized/disconnected canonic units are what I term "memes."

9. In The Selfish Gene (1976) Richard Dawkins coined the term meme to define "a self replicating unit of cultural transmission, or 
a unit of imitation." Dawkins and many others (e.g. Bloom in The Lucifer Principle) find the cultural units in ideas. I choose to stick with the gene analogy and apply the term to the minimal units of cultural memory. In spite of the huge difference in size (i.e. between Christianity and 'tilting at wind mills' as memes) a basic similarity in conceptualization remains. All usages of the term share biology as a basic metaphor for describing the life cycle of memes. Like genes, memes carry the potential for (re)constructing or activating much larger structures (i.e. the discarded/forgotten detailed memory of the text in which the meme originated). Like genes, memes can undergo mutations.

10. Mutations occur in two -sometimes simultaneous- stages: depletion of the semantic content of the decontextualized meme and acquisition of new meanings. When that happens it is no longer the mental representation of the original artifact that exists in the cultural memory, but only its trace (e.g. Romeo and Juliet come to represent happy lovers).

11. Prominent attributes of imported cultural objects can, therefore become "memes" of a host culture. Because of the mass media, starting with print-culture, Cultural Memory is trans-lingual and trans-historical. However, acquiring its meanings in different cultural contexts, the same meme (as signifier) might be signified differently in different cultural communities. Or, a meme may be signified in different ways in the same group, but there usually is a dominant signification that characterizes a community or subcommunities.

12. This semantic versatility is another manifestation of the creative freedom principle that Alter outlines in his discussion of 
canonicity and creativity: "Knowledge of received texts and recourse to them constitute the [trans-historical] community, but the texts do not have a single authoritative meaning, however much the established spokesmen for the canon at any given moment may claim that is the case." The big difference between creative freedom on the web and that demonstrated by Alter in the works of great masters is of course that the former is often the result of ignorance and/or indifference while the latter is grounded in knowledge and intellectual struggle.

13. New memes and new significations are not necessarily produced on the web, but the process of disassociation is augmented. Moreover, responses to representations of or references to a canonic text provide a much wider illustration of the cultural status of the original canonic work. Hence the focus on web-logs.

We can now turn to the study of the linguistic unit Don Quixotism (Don Kishotiyut in Hebrew) and the idiomatic meme 'tilting at windmills' on Israeli blogs. The two are actually inseparable in Israeli culture.

In a questionnaire designed to establish a list of the western canonic works best known in contemporary Israeli-Jewish culture, visual representations of the windmills scene were identified by $98 \%$ of the participants. $95 \%$ of those who identified the referenced texts have not read Don Quixote. For most of them the term Don Kishot is linked only with this meme. This episode is actually a weak support for viewing D.Q. as an idealist who tries to make the world a better place and fights the forces of evil against all odds -yet this is the dominant Israeli concept of Don Quixote. The temporary rescue of the young shepherd $(I, 4)$ or the liberation of the galley slaves $(1,22)$ would be much better choices. Windmills are not enemies of 
mankind and do not represent social oppression. But probably because it is both an idiom and a meme, 'tilting at windmills' is the strongest meme in Israeli cultural memory as the latter is articulated in Israeli cyberspace. The following illustrations have been chosen to prove and explain the claims concerning the meme's popularity and its established signification.

\section{Ex.1 Recognized Icon - depleted Meme}

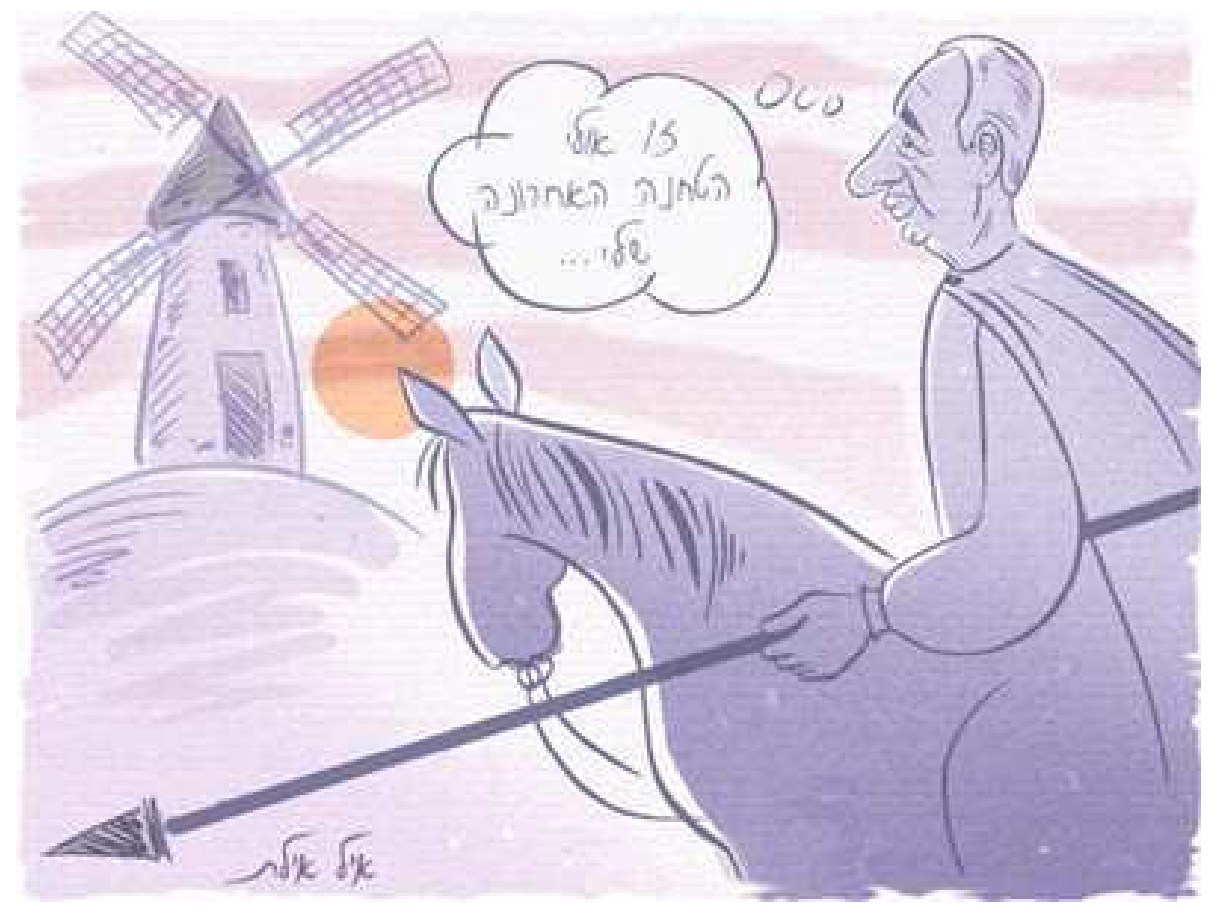

This caricature was published in the summer of 2007, during Shimon Peres' race for the presidency. We used it in 2008. People who were familiar with Cervantes' novel (students of comparative literature) liked it, but thought that the pun on the homophony between the Hebrew words for mill ('takhana') and station ('thakhana') elicited and sustained the comic effect. Activating the source was deemed unnecessary and problematic: the fact that the windmill stands for a coveted object, not an enemy, distances it from the established significations of the meme. The "constant loser" trait that could be brought in by the original context can be attributed directly to Peres. The caricature, then, illustrates 'memetic' depletion; the 190 comments, praising or criticizing the caricature and its author, supporting (very few) or criticizing 
Peres' ambition' support this claim. Although it is safe to assume (on the basis of the study mentioned earlier and described in Ben-Porat 2009) that most commentators recognized the reference to the meme it carried no meanings as far as most of them were concerned.

Only 22 commentators (out of 190 ) refer to the allusion. 3, probably by the same author, are signed Don Kishot, but do not mention the text or any aspect thereof in the posts. Other indicate their identifications by referring to Peres as Knight, by calling him Don Quishot, or by punning on the name: Don Guikhote [הטוחיג] , [ = = you cannot make it," or on the iconic windmill: "a knight in Mill" [לימב] hinting at Peres' old age and his worthlessness. One revealed the source of his familiarity by quoting the 1st line from one of the best known songs from the musical Man of La Mancha: "Dream the impossible dream!" Others mention other characters: "Who is the fat squire?" or "This time too, Sancho Panza will be the winner" - both referring to Rubi Rivlin's (the other contender) chubbiness. The issue of Sonia, Peres' wife who opposed the move, and mentioned a few times in the commentaries, appears in one post as "Poor Dulcinea is in critical condition and he sets off to travel around the world" (signed by Sancho). There are only 3 explicit references to the meme: 1 ) "Don Kishot became a symbol for an unrealistic person who fights the wind" a complete dismissal of both the realistic and the accepted symbolic meaning of the windmills. 2) "Peres, the government is a windmill, fight it so we get rid of it" -complete disregard for the character and the outcome of Don Quixote's adventures; 3) "It suits Peres to reach a nuclear installation" -a reference to Israel's nuclear reactor in Dimona (one of Peres' great achievements) and simultaneously a contemporary tenor for the windmills as vehicles for dangerous technology. Obviously, as the caricature cannot evoke the dominant Israeli signification of Don Quixotism, that of the unflinching idealist, most people ignore it and treat it as irrelevant. Those that acknowledge the reference's existence seem to use it as an opportunity to 
show their comic abilities rather than treat it as a semantically valid feature of the caricature.

\section{Example 2. Interpretation of a depleted meme}

A trip to the Golan Hights (tapuz, 31.05.07)

Tamax's (pseudonym) blog is devoted to photography and consists of pictorial descriptions of trips in Israel and abroad. This post describes the blogger's thoughts upon a trip to the Golan Hights (Israel) and in particular his sighting of electricity generating turbines using wind as their source of energy. Although this is certainly a green project to be cherished for the sake of the environment, it brought to the blogger's mind "The Tilting of the windmills" episode.

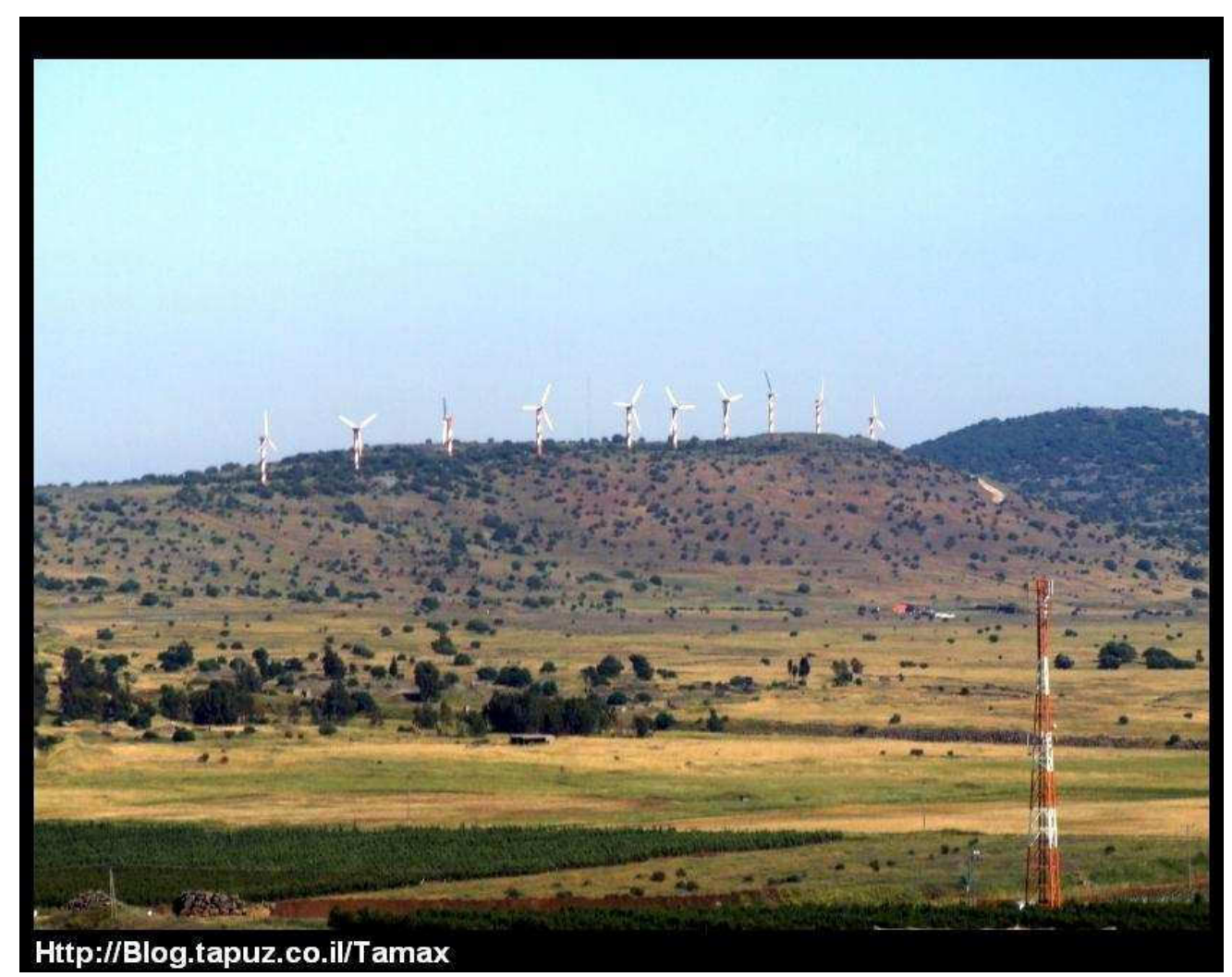

ןוד ומכ םהב ונמחלנ אל םנמוא ,'יקנעה םלדוגו םתמצועמ םימהדנ ונייהו ,רתוי ונברקתה ונחנא בוכרה וסנפ ו'צנאם ןמאנה ורזועו הטנניסור ותסוס לע בוכרה טושיק ווד דציכ ו'יבהל ןתינ וכא רא טושיק םיירזכא םייקנעל םתוא ומידו חור תונחטב ומחלנ רמוח לע. 
As we drew closer we were awed by their power and huge size. Indeed we did not attack them as Don Quixote did, but we could understand how the knight on his horse, Rocinante, together with his loyal helper Sancho Panza tilted the windmills likening them to cruel giants.

The blogger's reference to the act of interpretation might indicate some familiarity with the novel, but does not prove it. Everything he says is known to anybody familiar with the meme. The tone and phrasing are indicative of the dominant Israeli conceptualization: the blogger can understand why D.Q. has likened the windmills to cruel giants. Gone are the hallucinations and the crazy action is subdued by the willed imaginings. At the same time the blogger connects what he sees with the novel only on the basis of the power the turbines emanate. He claims to understand what caused D. Q.'s fears and in this way weakens the activation of the dominant conceptualization. In this way the blogger's use of the canonic reference tends toward enhancing the meme's semantic depletion' without endowing it with any new signification.

All of the 18 responses contain expressions of the delight the viewers felt at looking on the pictures, the wonder they felt in front of the turbines, or the love they felt towards the photographed landscape. No one commented on the importance of clean energy or on the tension between the wilderness in which they are situated and the turbines. Needless to say, no one made any political remark (Syria lost the Golan Heights to Israel in the 67 [six days] war). Only one response reacted to the reference to Don Quixote by punning on the way the name is pronounced in Hebrew: "I loved the image (donkey-shot)," showing no sign of activating the novel or any familiarity with Unamuno's famous anti-technological tirade.

The fact that the responses have been mostly emotional, indicating the commentators' delight and sympathy, might weaken my conclusion that the findings (with respect to this example) enhance the notion of "depleted" memes. However, even if it is true, and the participants in this multi-dialogue may possess more knowledge of the canonic segment -and the original text- 
then the short responses reveal, the depletion process is underlined. Among the many potential readers of the blog and the comments there will be many who become acquainted with the meme as a depleted entity.

\section{Ex. 3. Assigning a new meaning to the meme}

Source: Israblog.nana10

Date: 20.01 .09

Blogger: dotted eggplant; 14 years old; female

Blog: eggplants, politics and dots

Post:

Two weeks ago (yes, terrible delay, stone me), on our way back from grandma, dad asked- "Have you ever thought what the author of D.Q. is talking about?"

The truth, I've never thought about it. So I tried. I did not quite succeed in finding an answer.

Then dad said - "A war against windmills is in principle a lost war."

This must be true. Windmills don't fight back. They are not even a threat. You cannot win because there is no battle.

This is correct, this thing. I need to know how to separate things.

May be I'm fighting windmills as well.

I don't want to be a crazy old man.

No context is given for the conversation. The blogger might have been asked to read the novel or some chapters and hated it. The second part of the post (not quoted here) is full of complaints about the stupidity of her teachers and class-mates. She does think of D.Q. as crazy. This could indicate the presence of a "crazy D.Q." meme in Israeli cultural memory but it is also a 
logical conclusion to her analysis of her father's articulation of the meme. A full circle has been completed: the madman became a heroic idealist by allegorization; the young Israeli literalizes the meme. Don Quixote is mad again.

As it is unlikely that the reading assignment consisted of less than 2 pages, we must try to explain why the father reduces the novel to the "tilting at windmills" episode. The simplest explanation would be the cultural position of this episode as a meme. The father may know nothing else about the novel. Or, trying to convince his daughter of the relevance of D.Q. to her life, the father chooses the dominant Israeli notion of Don Quixote.

\section{Ex. 4 Ideological justification of the meme}

Site: tapuz

Date: 20.2 .07

Blogger: suki da yo; age: unknown; female

Post: Don Kishot

And I don't understand why Don Kishot symbolizes hopeless wars.

When has that [fighting a hopeless justified war] become a bad thing? A few days ago Dan Margalit said in Ha'aretz that all those who uncover corruptions have a Quixotic character trait, and I really loved that.

Somehow, when we were not paying attention, we stopped believing that we can change the world. A single man facing windmills. Or giants. After all, it is so easy to lock ourselves in and become impenetrable, to harden the heart, to mock people who believe in something and go with it all the way, even with respect to loved ones. It is so easy to think that "I cannot change the world in any case, so why bother to try?"

It does not work that way. If we stretch what Dan Margalit said -Every revolutionary, dissident, fighting globalization, governments, racism, capitalism, or anything symbolizing evil has it. To believe that I, by the strength of my will can make a 
difference is a little crazy, megalomaniac, and essentially unrealistic.

Reality is always stranger than any written plot. And it is indeed this blindness to reality that brings about the major positive changes. To my mind.

It is a pity that not all of us win a Sancho Panza who will follow us even at the highest moments of madness.

The blogger concludes the post by presenting a picture of a skeletal D.Q. on a skeletal Rocinante, dedicating the post to the people who changed the world by their will power or have been worn out by the constant struggle against the surrounding cynicism and mockery, and telling her readers she is looking for an optimistic depiction of D.Q.

\section{Conclusion}

This strong reiteration of the positive meme might help us understand why it has been almost from the beginnings of Israeli Hebrew culture the dominant conceptualization. Of course dominance could be explained by the scene's idiomatic position in the language -an idiom can be imported thru translations just as a meme. However, the idiom still carries the idea of imaginary enemies and/or the impossibility of success. Most of the examples I collected on American sites represent this conceptualization. But if we recall the Quixotic trait of the Zionist project, and of its avant-gardist elite force the Kibbutz movement, we can see why our Don Kishot had to be stripped of his megalomania as well as hallucinations and be dressed in Unamuno's allegorical garb. It is hard to guess what will happen now to the 'tilting at windmills' meme in particular or to the great works of the canon in general, when the collapse of the heroic dreams is joined by the web's enhancement of depletion processes. I can only hope that the accessibility of canonic texts and of explicit and explicated links between memes and other avatars and their canonic sources will keep canonic works in active cultural memory. I am 
sure that great writers, even using computers or writing hypertexts will go on using the canon in complex, creative and meaningful ways.

\section{References:}

ALTER, Robert. 1975. "The Mirror of Knighthood and the World of Mirrors" in Partial Magic: the Novel as a self conscious genre. Berkeley and Los Angeles: University of California Press, 1-29.

.2000. Canon and Creativity: Modern Writing and the Authority of the Scriptures. New Haven: Yale University Press.

BEN-PORAT, Ziva. 2009. "The Western Canon in Hebrew Digital Media." Neohelicon 36:2, 503-520.

DAWKINS, Richard. 1976. The Selfish Gene. Oxford: Oxford U.P. 